\title{
Native and alien tree insect pests: climate change impact and economic losses in Northwestern Russia ${ }^{\dagger}$
}

\author{
Andrey Selikhovkin 1,3,*, Sergey Merkuriev ${ }^{2,3}$, Alexander Khodachek ${ }^{4}$ \\ 1 Saint Petersburg State Forest Technical University, Saint Petersburg, Russia, a.selikhovkin@mail.ru \\ 2 Pushkov Institute of Terrestrial Magnetism of the Russian Academy of Sciences, Saint Petersburg Filial, Saint \\ Petersburg, Russia, sam_hg@hotmail.com \\ 3 Institute of Earth Sciences, Saint Petersburg State University, Saint Petersburg, Russia, \\ 4 National research university Higher school of economics, Saint Petersburg, Russia, hodachek@hse.ru \\ * Correspondence: a.selikhovkin@mail.ru \\ + Presented at the 1st International Electronic Conference on Entomology (IECE 2021), 1-15 July \\ 2021; Available online: https://iece.sciforum.net/.
}

Citation: Selikhovkin, A.; Merkuriev S.; Khodachek A. Native and alien tree insect pests: climate change impact and economic losses in Northwestern Russia, in Proceedings of the 1st International Electronic Conference on Entomology, 1-15 July 2021, MDPI: Basel, Switzerland, doi:10.3390/IECE-10412

Published: 30 June 2021

Publisher's Note: MDPI stays neutral with regard to jurisdictional claims in published maps and institutional affiliations.

Copyright: () 2021 by the authors. Submitted for possible open access publication under the terms and conditions of the Creative Commons Attribution (CC BY) license (http://creativecommons.org/licenses /by/4.0/).

\begin{abstract}
In the last 20 years, the ranges of some native and alien phytophagous insects have noticeably expanded northward in the European part of Russia. A simple deterministic linear model reliably describes the observed temperature dynamics for the last 120 years showing confident temperature increase. It is a worrying trend bearing in mind that such change may promote insect outbreaks and favor the arrival of novel unwanted pests. Here we discuss climate change impact and provide preliminary assessment of economic losses due to invasive insects in Northwestern Russia.
\end{abstract}

Keywords: alien insect pests, distribution, temperature dynamics, economic losses, Northern European Russia

\section{Introduction}

Native and alien insect pests can significantly affect tree health in forests and urban ecosystems that can result in a cascade of environmental, social and economic problems [1,2]. These problems can especially be dramatic on the northern territories largely facing climate change [3]. Temperature is one of the key factors affecting the population characteristics of insects, including population dynamics and range expansion [4,5]. In the last two decades, the distribution of some native and invasive insects and their outbreaks led to a large-scale decline of tree plantations in the Northern European Russia, in particular in Saint Petersburg, Leningrad Region, the Republic of Karelia and Arkhangelsk Oblast. For example, the outbreak of the European spruce bark beetle Ips typographus Linnaeus, 1758 and further distribution of Scolytus spp. (Coleoptera: Curculionidae, Scolytinae) were observed in 2003-2015 already in northern territories [1,6-9].

Despite tree decline and malfunctioning of native ecosystems and urban plantations due to insect pests, the factors favoring inset distribution and outbreaks have hardly been studied in the northern regions of the European Russia. Out study overviews the distribution of tree insect species, analyses temperature dynamics and provides preliminary assessment of economic consequences associated with native and alien pests in the region of Saint Petersburg and adjacent northern territories of Russia.

\section{Methods}

We examined city plantations in Saint Petersburg in 2020-2021, surveyed national literature and revised data on detection and further distribution of alien and native tree insect species. Here we focused on following tree insects: Scolytus multistriatus (Marsham, 1802), S. scolytus (Fabricius, 1775), S. pygmaeus (Fabricius, 1787), Ips amitinus (Eichhoff, 1872) (Coleoptera: Curculionidae, Scolytinae), Agrilus planipennis (Fairmaire, 1888) (Coleoptera: Buprestidae), Phyllonorycter issikii (Kumata, 1963), Cameraria ohridella Deschka et Dimić, 1986, and Acrocercops brongniardella (Fabricius, 1798) (Lepidoptera: 
Gracillariidae).

Temperature dynamics was studied in for the past 120 years (from 1900 to 2020) using regression analysis [10]. The average annual temperature and the average temperature for the growing season (May-September) were analyzed for Saint Petersburg, the Republic of Karelia (Sortavala) and Murmansk region (Kandalaksha) (Figure 1). A simple deterministic linear model of temperature dynamics was used.

The economic losses associated with alien insects were preliminarily estimated for the following species: Scolytus multistriatus, S. scolytus, S. pygmaeus, and Agrilus planipennis, and concerned exclusively the area of Saint Petersburg. For that, we took into account the cost of dead trees removal and the cost of new tree planting in the city. The service costs corresponded to those listed for Saint Petersburg in the document TERr 81-04-2001 subsection "Improvement" TERr-2001-68. The estimations were converted from RUB to EUR (2001 value).

\section{Result and Discussion}

\subsection{Overview of invasions by alien tree insects}

For a long time, the elm bark beetles Scolytus multistriatus (Marsham), S. scolytus (Fabricius) and S. pygmaeus (Fabricius) (Coleoptera: Curculionidae, Scolytinae) were not known from Leningrad Region and Saint Petersburg. In the end of the 20th - the beginning of the 21st centuries, the species composition of the genus Scolytus in of the Leningrad Region changed [11]. Scolytus multistriatus was reported from Saint Petersburg area in 1997 [11-13]. Another species, S. scolytus was discovered here in 2000 (in the floodplain of the river Sablinka, Tosno area) [11,13]. The northernmost findings of S. multistriatus and $S$ scolytus were made in the parks of the city Vyborg [13]. Scolytus pygmaeus was found in several districts of Saint Petersburg in 2012 [14,15]. It should be noted that these species are still unknown in southwestern Finland located in relative proximity to the Karelian Isthmus. In the latter, these species have already been found. The Scolytus species are a vector of pathogenic fungi Ophiostoma ulmi (Buisman) Nannfeldt and Ophiostoma novo-ulmi (Brasier) (Ascomycota: Ophiostomataceae) that cause Dutch elm disease and subsequent mass decline of elms in Saint Petersburg and the surrounding territories $[2,16-18]$.

The emerald ash borer Agrilus planipennis (Fairmaire) (Coleoptera: Buprestidae) is a dangerous invasive pest of ash originating from East Asia [19]. For the first time, this insect was discovered in Saint Petersburg in 2020. It was documented in several city districts (Petrodvorts, Morskaya, Suvorovskaya and Gostilitskoye Highway) [20,21]. Interestingly, until recently the emerald ash borer was known only from the northwestern outskirts of Tver, located $500 \mathrm{~km}$ southwest of Saint Petersburg [22]. The suggested time of the pest appearance in Saint Petersburg is 2014-2016 [20]. The survey done in the period from November 2020 to April 2021 revealed a new foci of the emerald ash borer in the Builders Park (Nevsky District) located in the eastern part of the city opposite the Petrodvorets district.

The small spruce bark beetle Ips amitinus (Eichhoff) (Coleoptera: Curculionidae, Scolytinae), a dangerous conifer pest, has been known in southwestern Finland and the Leningrad region since the middle of $20^{\text {th }}$ century [11]. Later on, this species rapidly spread towards north. At the end of 1996, it reached Murmansk region [12] and in 2011 was documented in the northern limit of conifer range [23]. This species is not a major pest of conifers in the European part of Russia. However, since recently it became known by its outbreak in Western Siberia leading to the massive decline of five needle pine, $\mathrm{Pi}$ nus sibirica Du Tour [24]. Thus, the potential danger posed by I. amitinus to the northern territories of European Russia remains to be re-evaluated.

Three invasive leafmining moths Phyllonorycter issikii (Kumata), Cameraria ohridella Deschka et Dimić, and Acrocercops brongniardella (Fabricius) (Lepidoptera: Gracillariidae), that develop on deciduous woody plants, were recorded in Saint Petersburg in the be- 
ginning of the $21^{\text {st }}$ century $[2,25]$. The present border of their secondary range in the north coincides with the northern border of the distribution of their host plants.

The lime leaf miner Ph. issikii, the East Asian pest [28] outbreaks in the European part of Russia [26-27]. This species occurred in Saint Petersburg in 1990s [29]. In 2002, the population density of this pest was already noticeable. In the city, the lime leaf miner gives two generations per year. The larvae of the third generation do not complete their development due to decreasing temperature in autumn. An increase in the population density of Ph. issikii was documented in the years with the early and warm springs and hot summers, in particular in 2002, 2008, 2013, and 2018 [2,25].

The horse-chestnut leaf miner C. ohridella is a pest on Balkan origin that has spread throughout most Europe over the past few decades [30]. In Saint Petersburg, this species was recorded in 2013; already in 2014 the local foci occurred in the city parks. In 2018-2020, about 30 mines per leaf were recorded. This species develops in Saint Petersburg in two generations $[2,25]$.

The third leafmining moth A. brongniardella, well-known pest of oak Quersus robur L., gives outbreaks in the south and center of the European part of Russia, Ukraine and Western Siberia [31, 32]. In Saint Petersburg, this species was discovered in 2018 [25]. The population density remains low; the species provides one generation per year.

The above cases demonstrate relatively recent occurrence of alien pests (Agrilus planipennis, Phyllonorycter issikii and Cameraria ohridella) and range expansion of native species (elm bark beetles Scolytus spp., Ips amitinus, and the leafminer Acrocercops brongniardella) in the Nonwestern Russia. All of these species are able to outbreak with possible environmental and economic consequences.

\subsection{Economic losses}

The green area of Saint Petersburg, excluding suburban forest, accounts for about 13 thousand hectares. In 2013-2020, around 35,000 elm trees died due to Dutch elm disease in the city. The total economic losses reached 1,300 million RUB, or 14.4 million EUR. So far, the recently arrived emerald ash borer attacked 165 trees. They all were cut down and utilized in autumn 2020 - spring 2021 causing economic loss of at least 5 million RUB, or 56 thousand EUR.

\subsection{Temperature dynamics}

The regression models have shown an increase of temperature indicators, i.e. the average annual temperature for all months and the average annual temperature for the growing season on the territory of Saint Petersburg, the Republic of Karelia and Murmansk region. The weakest correlation was recorded for Murmansk region (Kanadalaksha) (Figures 1, 2). The temperature increase was pronounced in 1980-2020 (especially the average annual temperatures for all months) in Kandalaksha (Figure 1) and in Saint Petersburg and the Republic of Karelia (the average annual temperature for the growing season) (Figure 2). 


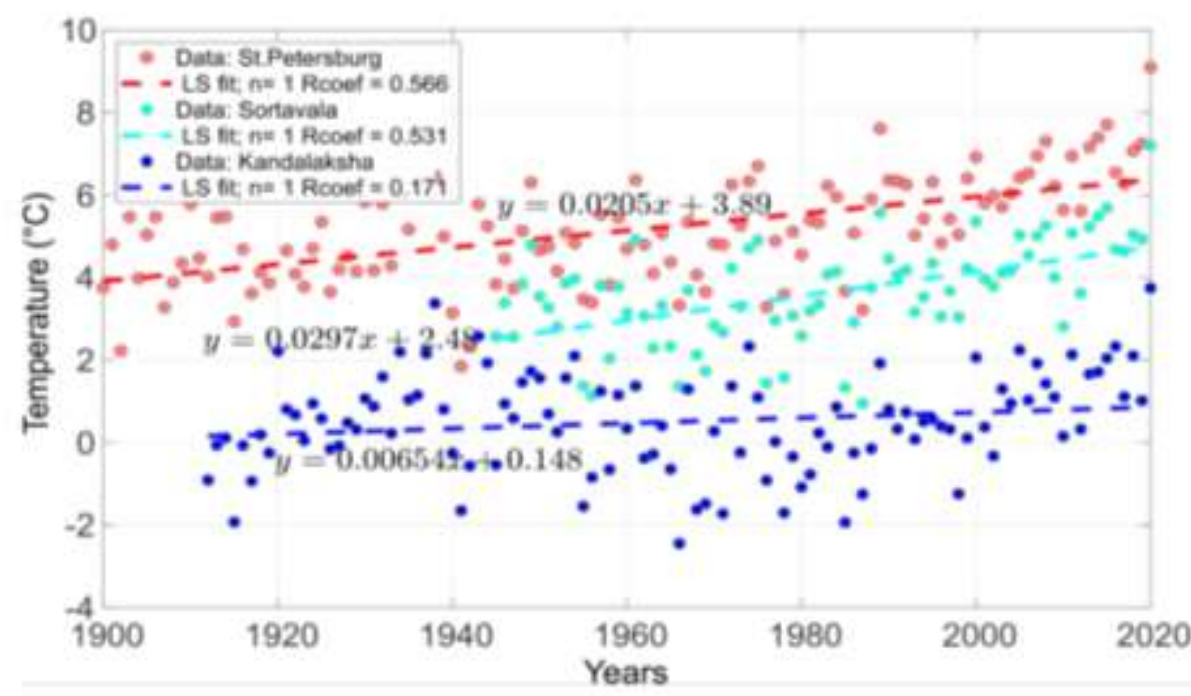

Fig.1 Annual average temperature dynamics in Saint Petersburg, Sortavala (the Republic of Karelia) and Kandalaksha (Murmansk region) in 1900-2020.

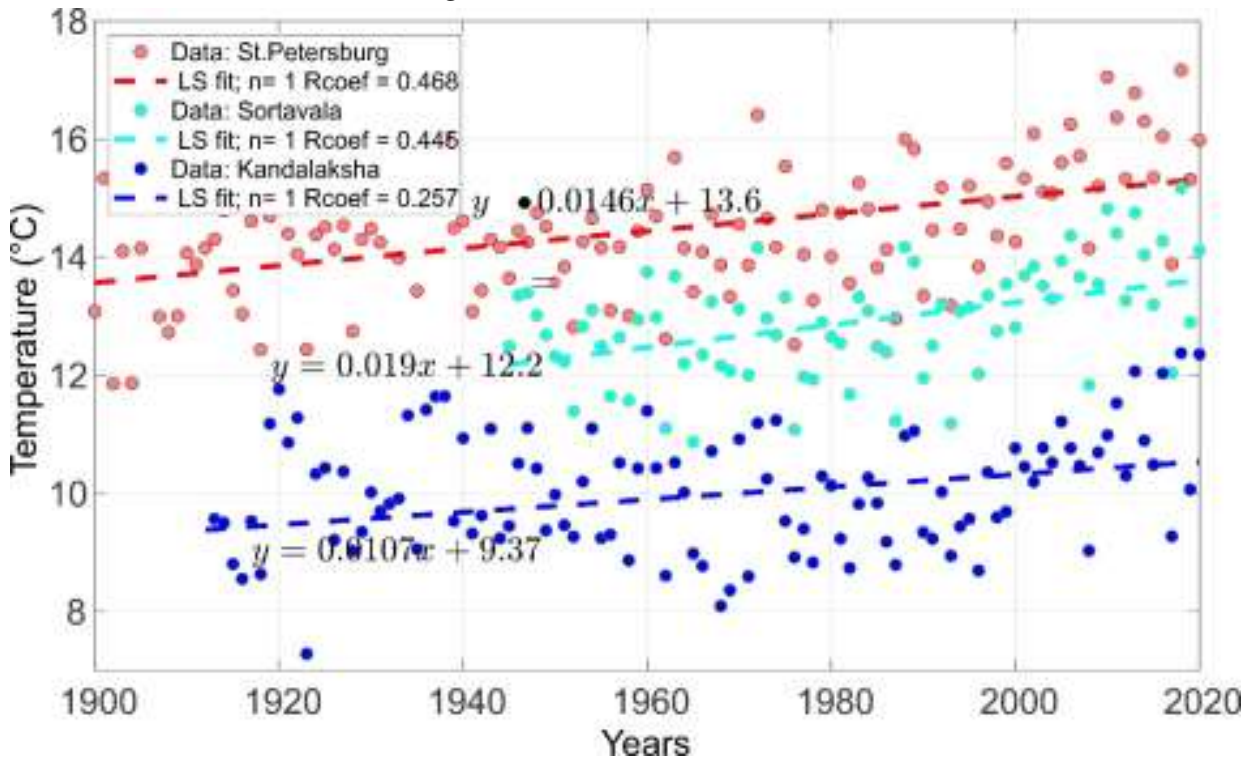

Fig.2 Annual average temperature dynamics for growing period (from May to September) in Saint Petersburg, Sortavala (the Republic of Karelia) and Kandalaksha (Murmansk region) in 1900-2020.

As increase in temperatures in St. Petersburg and Karelia in recent decades could contributed to the expansion of alien species to the north. In the near future, if the increase in the temperatures takes place during vegetation period, it will likely promote population density increase in tree insect pests. In Phyllonorycter issikii, Cameraria ohridella and Acrocercops brongniardella populations an additional generation may occur due to prolonged vegetation period and warm autumns. The temperature increase may also boost the development and further spread of Agrilus planipennis in Saint Petersburg. The bark beetles, especially Ips amitinus, I. typographus etc. will also react to climate warming providing significant damage to conifers in the northern regions. In this regard, the occurrence of severe outbreaks in the native bark beetles in 2010-2017 in spruce and pine forests of the Karelian Isthmus, the south of Karelia and Arkhangelsk Region confirms this possibility [6-9]. A striking example is an outbreak of elm bark beetles Scolytus spp. and significant decline of elms on the northern border of the host tree range.

\section{Conclusions}


The ongoing temperature changes may lead to the increase in the population density of the studied dendophagous pests in the near future. The outbreaks of spruce and pine pests may result in pronounced economic losses due to death of coniferous stands both in forests and man-made plantations in Saint Petersburg, Leningrad Region and the Republic of Karelia.

Author Contributions: Conceptualization, AS; methodology, AS, SM, AK; software SM, validation AS, SM; investigation, AS, SM, AK; writing the original draft, AS; project administration, AS; funding acquisition, AS. All authors have read and agreed to the published version of the manuscript.

Funding: This research was funded by the Russian Science Foundation, project № 21-16-00065, https://rscf.ru/en/project/21-16-00065/.

Institutional Review Board Statement: Not applicable.

Informed Consent Statement: Not applicable.

Data Availability Statement: Data are available on request from the corresponding author.

Acknowledgments: We thank Natalia Kirichenko (Krasnoyarsk, Russia) for her comments on the early manuscript version.

Conflicts of Interest: The authors declare no conflict of interest.

\section{References}

1. Maslov, A.D. The European spruce bark beetle and drying up of spruce forests. Moscow, VNIILM. 2010, 138. (in Russian)

2. Selikhovkin, A.V., Drenkhan, R., Mandelstam, M.Yu., Musolin, D.L. Invasions of insect pests and fungal pathogens of woody plants into the North-Western part of the European Russia. Vestnik of Saint-Petersburg University. Earth Sciences. 2020, 65(2), 263-283. (in Russian)

3. Anisimov, O.A., Vaughan, D.G., Callaghan, T.V., Furgal, C., Marchant, H., Prowse, T.D., Vilhjálsson H., Walsh, J.E. Polar regions (Arctic and Antarctic). Climate Change 2007: Impacts, Adaptation and Vulnerability. In Contribution of Working Group II to the Fourth Assessment Report of the Intergovernmental Panel on Climate Change; Parry, M.L., Canziani, O.F., Palutikof, J.P., van der Linden, P.J., Hanson, C.E., Eds., Cambridge University Press, Cambridge. 2007, 653-685.

4. Dixon, A.F.G., Honěk, A., Keil, P., Kotela, M.A.A., Šizling, A.L., Jarošek, V. Relationship between the minimum and maximum temperature thresholds for development in insects. Funct Ecol. 2009, 23, 257-64.

5. Régnière, J., Powell, J., Bentz, B., Nealis, V. Effects of temperature on development, survival and reproduction of insects: Experimental design, data analysis and modeling. J Insect Physiol. 2012, 58(5), 634-647.

6. Zhugunov, A.V., Semakova, T.A., Shabunin D.A. Massive destruction of forests in the northwest of Russia. In Forest biological research in the northwest of the taiga zone of Russia: results and prospects. Materials of the scientific conference dedicated to the 50th anniversary of the Forest Institute of the Karelian Scientific Center of the Russian Academy of Sciences. Krutov, V.N., Gromtseva, A.N., Predtechenskaya, O.O. Petrozavodsk Eds., Karelian Scientific Center RAN, Russia. 2007, 42-52. (in Russian)

7. Shabunin D.A Monitoring the state of forests in the northwest of the Russian Federation affected by mass drying out, researching the causes of drying out and developing control measures: research report (concluding) of FGU. SPbNIILKh, St. Petersburg, Russia. 2005, 121. (in Russian)

8. Tuchina, O.P., Yuriev, A.N., Podgornikh, P.V., Tuchina, O.P., Yuriev, A.N., Podgornikh, P.V. A brief overview of the sanitary and forest pathological state of the forests of the Arkhangelsk region for 2014 and forecasts for 2015. Arkhangelsk, Russia. 2015, 28. (in Russian)

9. Selikhovkin, A.V., Akhmatovich, N.A., Varentsova, E.Yu., Popovichev, B.G. Regeneration of European Spruce Bark Beetle and Other Wood Pathogens in forests of the Karelian Isthmus. Russian Journal of Forest Science. Lesovedenie. 2018, 6, 426-433.

10. All Russian Research Institute of Hydrometeorological Information - World Data Center. Hydrometeorology data service system: http://aisori-m.meteo.ru/waisori/index0.xhtml (accessed 01 June 2021).

11. Mandelshtam M.Yu., Selikhovkin A.V. Bark and ambrosia beetles (Coleoptera, Curculionidae: Scolytinae) of North-Western Russia: history of the study, composition and genesis of the fauna. Entomol. Rev. 2020, 99(3), 631-665.

12. Mandelshtam, M.Yu. New data on the fauna of bark beetles (Coleoptera, Scolytidae) of Leningrad Province. In Problemy entomologii v Rossii. Proc. of the 11th Congr. of the Russian Entomological Society. Medvedev, G.S., Ed. Zool. Inst., St. Petersburg, Russia. 1998, 2, 23. (in Russian)

13. Popovichev, B.G. Bark beetles in the northern districts of St. Petersburg. Lesn. Vestn. 2000, 6(15), 135. (in Russian) 
14. Mandelshtam, M.Yu., Khairetdinov, R.R., Additions to the check list of bark beetles (Coleoptera, Curculionidae: Scolytinae) of Leningrad Province, Russia, Entomol. Rev. 2017, 97(7), 893.

15. Shcherbakova, L.N. and Mandelshtam, M.Yu. Elms of St. Petersburg: the final warning. In The Kataev Memorial Readings - VIII. Pests and Diseases of Trees in Russia. Proc. of the Int. Conf., St. Petersburg, Musolin, D.L., Selikhovkin, A.V., Eds., St. Petersburg, Russia. 2014, 97. (in Russian)

16. Kalko, G. V. Dutch elm disease in St. Petersburg. Mycology and Phytopathology. 2008, 42(6), 564-571. (in Russian)

17. Faccoli, M., Santini, A. Dutch elm disease and elm bark beetles: Pathogen-Insect Interaction. In Vector-mediated transmission of plant pathogens. The American Phytopathological Society. Brown, J.K., Ed. 2016, 6, 74-86.

18. Jürisoo L., Selikhovkin A.V., Padari A, Shevchenko S.V., Shcherbakova L.N, Popovichev B.G., Drenkhan R. The extensive damage to elms by Dutch Elm Disease agents and their hybrids in northwestern Russia. Urban For Urban Green. 2021, https://doi.org/10.1016/j.ufug.2021.127214 (in press).

19. Herms, D.A., McCullough, D.G. Emerald Ash Borer Invasion of North America: History, Biology, Ecology, Impacts, and Management Daniel. Annu. Rev. Entomol. 2014, 59, 13-30.

20. Volkovitsh, M.G.; Bienkowski, A.O.; Orlova-Bienkowskaja, M.J. Emerald Ash Borer Approaches the Borders of the European Union and Kazakhstan and Is Confirmed to Infest European Ash. Forests. 2021, 12(6), 691.

21. Volkovitsh, M.G.; Suslov, D.V. The first record of the emerald ash borer, Agrilus planipennis Fairmaire (Coleoptera: Buprestidae), in Saint Petersburg signals a real threat to the palace and park ensembles of Peterhof and Oranienbaum. In Dendrobiotic Invertebrates and Fungi and their Role in Forest Ecosystems. The Kataev Memorial Readings-XI. Proc of the All-Russia Conference with International Participation. Musolin, D.L., Kirichenko, N.I., Selikhovkin, A.V., Eds. SPbSFTU, Saint Petersburg, Russia. 2020, 121-122. (in Russian)

22. Musolin, D.L.; Selikhovkin, A.V.; Peregudova, E.Y.; Popovichev, B.G.; Mandelshtam, M.Y.; Baranchikov, Y.N.; Vasaitis, R. North-Westward Expansion of the Invasive Range of Emerald Ash Borer, Agrilus planipennis Fairmaire (Coleoptera: Buprestidae) towards the EU: From Moscow to Saint Petersburg. Forests. 2021, 12, 502.

23. Shcherbakov, A.N., Nikitsky, N.B., Polevoi, A.V., and Humala, A.E. On the fauna of beetles (Insecta, Coleoptera) of Pasvik Nature Reserve. Vestn. Mosk. Gos. Univ. Lesa - Lesn. Vestn. 2013, 6(98), 16-21.(in Russin)

24. Kerchev, I.A., Mandelshtam, M.Yu., Krivets, S.A., Ilinsky, Yu.Yu. Small spruce bark beetle Ips amitinus (Eichhoff, 1872) (Coleoptera, Curculionidae: Scolytinae): a new alien species in West Siberia. Entomol. Rev. 2019, 99(5), 639.

25. Selikhovkin, A.V., Baryshnikova, S.V., Denisova, N.V., Timofeeva, Yu.A. Species Composition and Population Dynamics of Dominant Dendrophagous Moths (Lepidoptera) in St. Petersburg and Its Environs. Entomol. Rev. 2018, 98(8), 963-978.

26. Ermolaev, I.V, Zorin, D.A. Ecological subsequences of Phyllonorycter issikii (Lepidoptera, Gracillariidae) invasion from the example of lime forests in Udmurtia. Zool. zh. 2011, 90(6), 717-723. (in Russian)

27. Ermolaev, I.V., Domrachev, T.B. The influence of generations number on the dynamics of lime leafminer Phyllonorycter issikii (Kumata, 1963) (Lepidoptera, Gracillariidae) in Udmurtiya. Russ J Biol Invasions. 2020, 4, 66-80.

28. Kirichenko, N.I., Akulov, E. N., Babichev, N.S., Mikhailova, I.A., Ponomarenko, M.G., Lopez-Vaamonde, C. Past distribution of tilia-feeding Phyllonorycter micromoth (Lepidoptera: Gracillariidae) in the Russian Far East based on survey of historical herbarium. Far East Entomol. 2019, 390, 19-32.

29. Popovichev B.G. New invasive species Phyllonorycter issikii in St. Petersburg. In Globalisation and landscape architecture: issues for education and practice. St. Petersburg. Glenn Stewart et al., Eds. Polytechnic Univ. publ. house, 2007, 202. (in Russian)

30. Jagiełło, R., Łakomy, P., Łukowski A., Giertych Marian J. Spreading-the-risk hypothesis may explain Cameraria ohridella oviposition in relation to leaf blotch disease. Arthropod Plant Interac. 2019, 13, 787-795.

31. Chursina, V. A., Vokhtantseva, K. V., Gayvas A. A. The main pest of English oak on the territory of the city of Omsk is the leaf blotch miner moth. In Innovative technologies in agriculture: Proc of the II Intern. scientific conf. Akhmedov I.G., Ed. SPb., SPbGLTU, Russia. 2016, 21-25. (in Russian)

32. Utkina, I.A., Rubtsov, V.V. The leaf blotch miner moth Acrocercops brongniardella F. (Lepidoptera: Gracillariidae) in Tellerman oakwood. In The Kataev Memorial Readings - X. Dendrobiotic Invertebrates and Fungi and their Role in Forest Ecosystems. Insects and Other Invertebrates. Proc. of the Int. Conf.. St Petersburg, Russia. Musolin, D.L., Selikhovkin A.V., Eds., 2018, 1, 104-105. (in Russian) 